OPEN ACCESS

Edited by:

Min Yue,

Zhejiang University, China

Reviewed by:

Abdelaziz Ed-Dra,

Moulay Ismail University, Morocco

Yanlong Jiang,

Jilin Agriculture University, China

*Correspondence:

Guangxing Li

ligx@neau.edu.cn

Dexing Ma

madexing@neau.edu.cn

tThese authors share first authorship

Specialty section: This article was submitted to Veterinary Infectious Diseases, a section of the journal Frontiers in Veterinary Science

Received: 03 December 2020 Accepted: 15 January 2021

Published: 23 February 2021

Citation:

Jia Z, Ma C, Yang X, Pan X, Li G and Ma D (2021) Oral Immunization of

Recombinant Lactococcus lactis and Enterococcus faecalis Expressing Dendritic Cell Targeting Peptide and Hexon Protein of Fowl Adenovirus 4 Induces Protective Immunity Against

Homologous Infection.

Front. Vet. Sci. 8:632218. doi: 10.3389/fvets.2021.632218

\section{Oral Immunization of Recombinant Lactococcus lactis and Enterococcus faecalis Expressing Dendritic Cell Targeting Peptide and Hexon Protein of Fowl Adenovirus 4 Induces Protective Immunity Against Homologous Infection}

\author{
Zhipeng Jia ${ }^{1,2 \dagger}$, Chunli Ma ${ }^{3 \dagger}$, Xuelian Yang ${ }^{1,2}$, Xinghui Pan ${ }^{1,2}$, Guangxing $\mathrm{Li}^{1 *}$ and \\ Dexing $\mathrm{Ma}^{1,2 *}$
}

${ }^{1}$ Heilongjiang Key Laboratory for Laboratory Animals and Comparative Medicine, College of Veterinary Medicine, Northeast Agricultural University, Harbin, China, ${ }^{2}$ Heilongjiang Key Laboratory for Laboratory Animals and Comparative Medicine, Harbin, China, ${ }^{3}$ Food College, Northeast Agricultural University, Harbin, China

Hepatitis-hydropericardium syndrome (HPS) causes severe economic losses in the global poultry industry. The present study aims to explore oral immunization of recombinant Lactococcus lactis and Enterococcus faecalis expressing Hexon protein of fowl adenovirus 4 (FAdV-4). The bacteria L. lactis NZ9000 and E. faecalis MDXEF-1 were, respectively, modified as host strain to deliver truncated Hexon protein ( $\Delta$ Hexon) or $\Delta$ Hexon protein fusing with dendritic cell (DC) targeting peptide (DC- $\Delta$ Hexon) on the surface of bacteria. The expression of target protein in L. lactis NZ9000 and E. faecalis MDXEF-1 were detected by western blot. To evaluate the immune responses and protective efficacies provided by the live recombinant bacteria, chickens were immunized with the constructed $\Delta$ Hexon-expressing bacteria three times at 2-week intervals, then experimentally challenged with hypervirulent FAdV-4/GX01. The results showed that oral immunizations with the four $\Delta$ Hexon-expressing bacteria

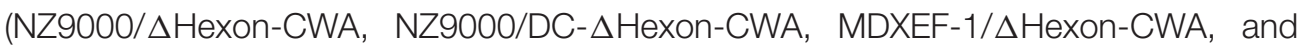
MDXEF-1/DC- $\Delta$ Hexon-CWA), especially the two bacteria carrying DC-targeting peptide, stimulated higher levels of $\Delta$ Hexon-specific sera $\lg G$ and secretory $\lg A$ (slgA) in jejunal lavage fluid, higher proliferation of peripheral blood lymphocytes (PBLs) and higher levels of Th1/Th2-type cytokines, along with significantly decreased virus loads in liver and more offered protective efficacies against FAdV infection compared with PBS and empty vector control groups $(p<0.01)$. For chickens in the group MDXEF-1/DC- $\Delta$ Hexon-CWA, the levels of aspartate transaminase (AST), alanine transaminase (ALT) and lactate dehydrogenase $(\mathrm{LDH})$ in sera, and the virus loads in livers were significantly decreased vs. the other three $\Delta$ Hexon-expressing bacteria $(p<0.01)$. The pathological changes in the hearts, livers, spleens and kidneys of chickens in MDXEF-1/DC- $\Delta$ Hexon-CWA group were relatively slight compared to infection control group and other three 


\begin{abstract}
$\Delta$ Hexon-expressing bacteria groups. The rate of protection in MDXEF-1/DC- $\Delta$ Hexon-CWA group was 90\%. The present work demonstrated that cell surface-displayed target protein and immune enhancers in L. lactis and E. faecalis might be a promising approach to enhance immunity and immune efficacy against pathogen FAdV-4 infection.
\end{abstract}

Keywords: FAdV-4, Hexon, Lactococcus lactis, Enterococcus faecalis, dendritic cell-targeting, oral immunization

\section{INTRODUCTION}

Fowl adenoviruses (FAdVs) are non-enveloped, double-stranded DNA viruses belonging to the Aviadenovirus genus of the Adenoviridae family. FAdVs are currently divided into 5 species (A-E) and 12 serotypes $(1-7,8 \mathrm{a}, 8 \mathrm{~b}, 9-11)(1,2)$. FAdV-4 usually infects 3-6 weeks old broilers showing a mortality rate of up to $80 \%$, and causes accumulation of transparent or strawcolored fluid in the pericardial sac and hepatitis (3-5). Hepatitishydropericardium syndrome (HPS) is one of the typical gross pathological changes in FAdV-4 infected chickens, which has been widely reported in several countries and regions such as Middle East (6), Germany (7), Korea (8), Malaysia (9), and Japan, India and Pakistan (10). In China, HPS caused by novel hypervirulent FAdV-4 has been reported since 2015 (11), which leads to significant economic losses to the broiler poultry industry. Therefore, exploration of vaccine aiming at preventing HPS has become a research hot spot.

Currently, inactivated vaccines and live attenuated vaccines prepared based on the FAdV-4 ON1 strain were characterized to be immunogenic and effective against FAdV-4 infection (12). Considering the potential reversion to virulence for attenuated vaccines, and the potential tumorigenicity of adenoviruses, the novel genetic engineering vaccines are still necessary to be explored. It is generally accepted that mucosal immunity represents the first line of defense, and mucosal vaccination can evoke protective mucosal immune responses against highly contagious virus via the oral route (13). In recent years, lactic acid bacteria (LAB) has been widely used as vehicles to deliver important antigens of pathogens, such as the circumsporozoite protein of Plasmodium falciparum (14), spike protein of SARSCoV-2 (15), the heavy-chain antigen of Clostridium botulinum serotype A neurotoxin and the Bacillus anthracis protective antigen (16). Previous studies have shown that the expression of FAdV-4 structural proteins, including Hexon, Penton, Fiber 1 and Fiber 2, in Escherichia coli and other expression systems could be used to develop subunit vaccines (17-22). However, the protective efficiencies of live recombinant LAB delivering structural proteins of FAdV-4 against homologous challenge have not been assessed until now. We and others also reported that live recombinant Lactococcus lactis NZ9000 delivering Eimeria 3-1E protein (23) and avian hepatitis E virus (aHEV) ORF2 protein (24), Enterococcus faecalis displaying Eimeria 3-1E protein (25), Lactobacillus plantarum expressing Eimeria tenella MIC2 protein (26) to some extent provided protective efficacies against poultry disease. Moreover, previous studies have confirmed that oral vaccination with genetically modified bacteria delivering dentritic cell (DC) targeting peptides and immunogenic antigens of pathogens enhanced antigen-specific mucosal immunity against homologous pathogen infection (27-30).

Based on the previous studies, we speculated that the effective mucosal and humoral immune responses evoked by oral immunization would be a promising means to prevent HPS caused by FAdV. In the present study, L. lactis NZ9000 and E. faecalis MDXEF-1 were used as host strains to express $\triangle$ Hexon proteins of FAdV, respectively. Meanwhile, DC targeting peptide was introduced to fuse with anchored $\Delta$ Hexon proteins to enhance the antigenic-specific immune responses. Then, the recombinant $L$. lactis and $E$. faecalis were used to immunize chickens via oral route, and the immune responses and protection against FAdV-4 challenge were evaluated.

\section{MATERIALS AND METHODS}

\section{Bacterial Strains, Plasmids, and Virus}

Details of the strains and plasmids used in this experiment are listed in Table 1. Lactococcus lactis NZ9000, E. faecalis MDXEF-1 (25), and derivative strains were grown at $30^{\circ} \mathrm{C}$ in GM17 broth (M17 containing 0.5\% glucose, Luqiao, Beijing) without shaking or on GM17 culture plate with 1.5\% agar. E. coli strains were cultured on Luria-Bertani (LB) medium (Hopebiol) at $37^{\circ} \mathrm{C}$. Chicken hepatoma cell line (LMH) (ATCC) was cultured in DMEM medium supplemented with $10 \%$ fetal bovine sera at $37^{\circ} \mathrm{C}$ in $5 \% \mathrm{CO}_{2}$. FAdV-4 strain GX01 (FAdV4/GX01, GenBank no. MH229946.1) used in the present study was isolated from a natural case of HPS by Prof. Guangxing Li in our laboratory. The virus was purified and propagated in the LMH cells.

\section{Animals}

Two male New Zealand rabbits weighing about $2 \mathrm{~kg}$ were obtained from a rabbit farm. Specific-pathogen-free (SPF) White Leghorn chickens and embryos were purchased from the Harbin Veterinary Research Institute (Heilongjiang, China). 9-day-old SPF chicken embryos were infected with serial 10fold dilutions of FAdV-4/GX01 $(0.2 \mathrm{~mL})$ onto each embryo's chorioallantoic membranes and incubated at $37^{\circ} \mathrm{C}$ for 10 days to calculate the $50 \%$ embryo lethal dose $\left(\mathrm{ELD}_{50}\right)$ according to the formula of Reed and Muench (32). In this study, animals were maintained on a 12 -h light/12-h dark cycle, with unrestricted access to food and drinking water. Animal experiments were performed according to the regulations (SRM12) of the Ethical Committee for animal sciences in Northeast Agricultural University, Heilongjiang Province, PR China. 
TABLE 1 | Strains and plasmids used in this study.

\begin{tabular}{|c|c|c|}
\hline Bacterial strain or plasmids & Relevant characteristics & Source or references \\
\hline \multicolumn{3}{|l|}{ Strain } \\
\hline E. coli $\mathrm{DH} 5 \alpha$ & $\begin{array}{l}\text { SupE44 } \Delta \text { lacU169( } \varphi 80 \text { lacZ } \Delta M 15) \text { hsdR17 recA1 endA1 gyrA96 } \\
\text { thi-1 relA1, plasmid-free. }\end{array}$ & TaKaRa, Dalian, China. \\
\hline E. coli BL21(DE3) & F-ompT hsdSB (rB- mB-) gal dcm (DE3), plasmid-free. & TaKaRa, Dalian, China. \\
\hline L. lactis subsp. cremoris NZ9000 & $\begin{array}{l}\text { Derivate strain of MG1363, with nisR and nisK genes for nisin } \\
\text { induction, plasmid-free strain. }\end{array}$ & $\mathrm{NIZO}$ \\
\hline E. faecalis MDXEF-1 & $\begin{array}{l}\text { Isolated from chicken and reserved by our laboratory (Chinese } \\
\text { patent ZL201410817717.5) }\end{array}$ & $(25)$ \\
\hline E. coli DH5 $\alpha /$ pMD19T- $\Delta$ Hexon & With plasmid pMD19T- $\Delta$ Hexon in E. coli DH5 $\alpha$. & This study \\
\hline E. coli BL21(DE3)/pET30a- $\Delta$ Hexon & With plasmid pET30a- $\Delta$ Hexon in E. coli BL21(DE3). & This study \\
\hline NZ9000/pTX8048 & With plasmid pTX8048 in L. lactis cremoris NZ9000. & This study \\
\hline MDXEF-1/pTX8048 & With plasmid pTX8048 in E. faecalis MDXEF-1. & This study \\
\hline NZ9000/pTX8048-SP- $\Delta$ Hexon-CWA & $\begin{array}{l}\text { With plasmid pTX8048-SP- } \Delta \text { Hexon-CWA in L. lactis cremoris } \\
\text { NZ9000. }\end{array}$ & This study \\
\hline NZ9000/pTX8048-SP-DC- $\Delta$ Hexon-CWA & $\begin{array}{l}\text { With plasmid pTX8048-SP-DC- } \Delta \text { Hexon-CWA in L. lactis cremoris } \\
\text { NZ9000. }\end{array}$ & This study \\
\hline MDXEF-1/ $\Delta$ Hexon-CWA & With plasmid pTX8048-SP- $\Delta$ Hexon-CWA in E. faecalis MDXEF-1. & This study \\
\hline $\begin{array}{l}\text { MDXEF-1/pTX8048-SP-DC- } \Delta \text { Hexon- } \\
\text { CWA }\end{array}$ & $\begin{array}{l}\text { With plasmid pTX8048-SP-DC- } \Delta \text { Hexon-CWA in E. faecalis } \\
\text { MDXEF-1. }\end{array}$ & This study \\
\hline \multicolumn{3}{|l|}{ Plasmid } \\
\hline pMD19T & High-efficiency TA cloning vector. & TaKaRa, Dalian, China \\
\hline pET30a & Escherichia coli expression vector. & Novagen, Madison, WI \\
\hline pMD19T- $\Delta$ Hexon & With fragment encoding $\Delta$ Hexon protein in pMD19T. & This study \\
\hline pET30a- $\Delta$ Hexon & With fragment encoding $\Delta$ Hexon protein in pET30a. & This study \\
\hline pTX8048 & $\begin{array}{l}\text { With fragment encoding signal peptide of secretion protein Usp45 } \\
\text { (SP). }\end{array}$ & $(31)$ \\
\hline pTX8048-SP- $\triangle$ ORF2-CWA & $\begin{array}{l}\text { With fragment encoding signal peptide of secretion protein Usp45 } \\
\text { (SP) and } \Delta \text { ORF2 protein in anchored form, no dendritic cell } \\
\text { targeting peptides. }\end{array}$ & $(24)$ \\
\hline pTX8048-SP-DC-3-1E-CWA & $\begin{array}{l}\text { With fragment encoding signal peptide of secretion protein Usp45 } \\
\text { (SP) and 3-1E protein in anchored form, contains dendritic cell } \\
\text { targeting peptides. }\end{array}$ & $(25)$ \\
\hline pTX8048-SP- $\Delta$ Hexon-CWA & $\begin{array}{l}\text { With fragment encoding signal peptide of secretion protein Usp } 45 \\
\text { (SP) and } \Delta \text { Hexon protein in anchored form, no dendritic cell } \\
\text { targeting peptides. }\end{array}$ & This study \\
\hline pTX8048-SP-DC- $\Delta$ Hexon-CWA & $\begin{array}{l}\text { With fragment encoding signal peptide of secretion protein Usp } 45 \\
\text { (SP) and } \Delta \text { Hexon protein in anchored form, contains dendritic cell } \\
\text { targeting peptides. }\end{array}$ & This study \\
\hline
\end{tabular}

\section{Preparation of Polyclonal Antisera Against $\Delta$ Hexon}

Virus DNA was extracted from semi-purified viral suspension using TaKaRa MiniBEST Viral RNA/DNA Extraction Kit Ver.5.0 (Takara, Beijing, China) according to the manufacturer's instructions. The target $\Delta$ Hexon gene fragments were amplified using primers pair $\Delta$ Hexon-F2 and $\Delta$ Hexon-R2 (Table 2) using prepared DNA as a template. The amplification parameters were as follows: $95^{\circ} \mathrm{C}$ for $5 \mathrm{~min}$, followed by 35 cycles of $95^{\circ} \mathrm{C}$ for $30 \mathrm{~s}, 57^{\circ} \mathrm{C}$ for $30 \mathrm{~s}$, and $72^{\circ} \mathrm{C}$ for $75 \mathrm{~s}, 72^{\circ} \mathrm{C}$ for $10 \mathrm{~min}$ and a $4^{\circ} \mathrm{C}$ hold. The amplified $\Delta$ Hexon gene fragments were inserted into BamH I and Xho I sites of pET30a vectors (Novagen, Madison, WI) to generate plasmid pET30a- $\Delta$ Hexon, which were then transformed into $E$. coli BL21(DE3) competent cells to produce recombinant positive $E$. coli cells. The positive bacteria were induced with the final concentration of $1 \mathrm{mM}$ Isopropyl $\beta$-D-Thiogalactopyranoside (IPTG) (Solarbio, Beijing, China) for $7 \mathrm{~h}$ at $37^{\circ} \mathrm{C}$ when optical density at $600 \mathrm{~nm}\left(\mathrm{OD}_{600}\right)$ reached 0.5 or 0.6 . The harvested cells were lysed by sonication, and the expression of $\Delta$ Hexon protein was analyzed by sodium dodecyl sulfate-polyacrylamide gel electrophoresis (SDS-PAGE). The expression and purification of $\Delta$ Hexon protein were carried out as previously described (35). Briefly, the target $\Delta$ Hexon protein fused with a $6 \times$ His tag was purified using a His-tag Protein Purification Kit (Beyotine Biotechnology) according to the manufacturer's protocol. $2 \mathrm{mg}$ of purified $\Delta$ Hexon protein mixed with $2 \mathrm{ml}$ of complete Freund's adjuvant (Sigma, USA) was used to immunize New Zealand white rabbits. The second, third, and fourth immunizations were boosted at 2-weeks intervals as the primary immunization except that the complete Freund's 
TABLE 2 | Primer sequences with their corresponding PCR product size.

\begin{tabular}{|c|c|c|c|c|}
\hline Name of primer & Primer sequences $\left(5^{\prime}-3^{\prime}\right)$ & Enzyme & PCR Product (base pairs) & Source or references \\
\hline$\Delta$ Hexon -F2 & CGCGGATCCGCGACTCCGCGGCTCCAGTAT & $\mathrm{BamH} \mathrm{I}$ & $1,230 \mathrm{bp}$ & This study \\
\hline$\Delta$ Hexon -R2 & GAGACTCGAGAGTGCCGAAGTAGAAGTTGG & Xhol & & \\
\hline$\Delta$ Hexon -F3 & CGCGGATCCGCGACTCCGCGGCTCCAGTAT & BamH I & $1,230 \mathrm{bp}$ & This study \\
\hline$\Delta$ Hexon -R3 & GGGGTACCAGTGCCGAAGTAGAAGTTGG & Kpnl & & \\
\hline $52 \mathrm{~K}-\mathrm{F}$ & ATGGCGCAGATGGCTAAGG & / & $176 \mathrm{bp}$ & (33) \\
\hline $52 \mathrm{~K}-\mathrm{R}$ & AGCGCCTGGGTCAAACCGA & / & & \\
\hline Ch IL-2-F & GTGGCTAACTAATCTGCTGTCC & / & $105 \mathrm{bp}$ & (24) \\
\hline Ch IL-2-R & GTAGGGCTTACAGAAAGGATCAA & / & & \\
\hline Ch IL-4-F & CTGTGCCCACGCTGTGCTTA & / & $83 \mathrm{bp}$ & This study \\
\hline ChlL-4-R & GGAAACCTCTCCCTGGATGTCA & / & & \\
\hline ChlL-10-F & GGCTCACTTCСTCСTCC & / & 112 bp & This study \\
\hline ChIL-10-R & TGACTITCACCTGCAGATG & / & & \\
\hline ChIFN- $\gamma-\mathrm{F}$ & CAAAGCCGCACATCAAACA & / & $80 \mathrm{bp}$ & $(24)$ \\
\hline ChIFN- $\gamma-\mathrm{F}$ & ПTССССTTCTTCACGCCATC & / & & \\
\hline Ch $\beta$-actin-F & GCCAACAGAGAGAAGATGACAC & / & $138 \mathrm{bp}$ & (34) \\
\hline Ch $\beta$-actin-R & GTAACACCATCACCAGAGTCCA & / & & \\
\hline
\end{tabular}

adjuvant was replaced by incomplete Freund's adjuvant (Sigma, USA). The specificity of antisera was detected by western blot, as previously described (35). The titer of the antisera was determined by enzyme linked immunosorbent assay (ELISA). In brief, $100 \mu \mathrm{L}$ of purified $\Delta$ Hexon protein $(10 \mu \mathrm{g} / \mathrm{mL})$ was added to each well in a 96-well plate and incubated overnight at $4{ }^{\circ} \mathrm{C}$. The plate was washed three times with PBST (PBS containing $0.05 \%$ Tween 20 ), then blocked with 5\% skimmed milk at $37^{\circ} \mathrm{C}$ for $1.5 \mathrm{~h} .100 \mu \mathrm{L}$ of two-fold serially diluted sera was added to each well and incubated for $1.5 \mathrm{~h}$ at $37^{\circ} \mathrm{C}$. After washing, the plates were incubated with HRP-conjugated goat anti-rabbit IgG (Sigma-Aldrich) diluted at 1:5000 for $1 \mathrm{~h}$ at $37^{\circ} \mathrm{C} .1 \mathrm{mg} / \mathrm{mL}$ of o-phenylenediamine and $0.01 \% \mathrm{H}_{2} \mathrm{O}_{2}$ were added $(100 \mu \mathrm{L}$ per well), and the reaction was stopped by $2 \mathrm{M}$ $\mathrm{H}_{2} \mathrm{SO}_{4}$. The absorbance was measured at $490 \mathrm{~nm}$ using a reader (Bio-Rad, USA).

\section{Identification of Recombinant $L$. lactis and E. faecalis Expressing $\Delta$ Hexon Protein}

The $\Delta$ Hexon gene fragment was amplified by primers pair $\Delta$ Hexon-F2 and $\Delta$ Hexon-R3 (Table 2), and subcloned into the BamH I and Kpn I sites of pTX8048-SP-CWA (containing cell wall-anchored sequence) or pTX8048-SPDC-CWA (containing cell wall-anchored sequence and dendritic cell-targeting peptide) to generate plasmids pTX8048SP- $\Delta$ Hexon-CWA and pTX8048-SP-DC- $\Delta$ Hexon-CWA, respectively (Figure 1A). The above two positive plasmids were confirmed by nucleotide sequence analysis, then were transformed into L. lactis NZ9000 and E. faecalis MDXEF1 competent cells by electroporation, respectively. The characterized positive bacteria were named NZ9000/ $\triangle$ HexonCWA, NZ9000/DC- $\Delta$ Hexon-CWA, MDXEF-1/ $\Delta$ Hexon-CWA, and MDXEF-1/DC- $\triangle$ Hexon-CWA, respectively. Meanwhile, recombinant bacteria NZ9000/pTX8048 and MDXEF1/pTX8048 were used as control. Recombinant positive
L. lactis and E. faecalis were cultured to $\mathrm{OD}_{600}$ values of 0.5 , then induced by a final concentration of $5 \mathrm{ng} / \mathrm{mL}$ nisin (Sigma-Aldrich) for $4 \mathrm{~h}$. The cell wall-anchored protein samples were prepared as previously described (31). In brief, cell pellets were washed and resuspended in TES $(10 \mathrm{mM}$ Tris- $\mathrm{HCl}$ pH 8.0, $1 \mathrm{mM}$ EDTA, 25\% sucrose). The buffer TES-LMR (TES containing $1 \mathrm{mg} / \mathrm{ml}$ lysozyme, $0.1 \mathrm{mg} / \mathrm{ml}$ mutanolysin, $0.1 \mathrm{mg} / \mathrm{ml} \mathrm{RNase)}$ was applied to digest cell walls. After centrifugation, the cell walls were pelleted and removed, and the cell wall-anchored proteins in the supernatant were precipitated with final concentration of $16 \%$ trichloroacetic acid (TCA). The target cell wall-anchored protein was resuspended. The prepared protein samples were separated by SDS-PAGE, and electrophoretically transferred to nitrocellulose membranes. The membranes were incubated with rabbit anti- $\Delta$ Hexon polyclonal antisera (1:1000), then reacted with horseradish peroxidase (HRP)-conjugated goat anti-rabbit IgG antibody (1:2000) (Sigma, USA). The immunoreactive protein bands were visualized using an ECL chemiluminescence detection kit (BeyoECL Moon).

To further testify the target $\Delta$ Hexon protein was displayed on the surface of recombinant L. lactis NZ9000 and E. faecalis MDXEF-1, indirect immunofluorescence assay (IFA) was performed. Briefly, the recombinant positive L. lactis and E. faecalis were cultured to $\mathrm{OD}_{600}$ values of 0.5 , and then induced by a final concentration of $5 \mathrm{ng} / \mathrm{mL}$ nisin (Sigma-Aldrich) for $4 \mathrm{~h}$. The bacterial cultures were washed twice with sterile PBS ( $\mathrm{pH} 7.2$ ), followed by centrifugation at $10,000 \times \mathrm{g}$ for $10 \mathrm{~min}$. Then the pellets were incubated with rabbit polyclonal antisera against $\Delta$ Hexon (1:200) (primary antibody) and goat anti-rabbit IgG conjugated to fluorescein isothiocyanate (FITC) (1:50, Solarbio) (secondary antibody). After washing, the fluorescence on the surface of recombinant bacteria were observed using fluorescence microscope (Leica DM2000). 
A
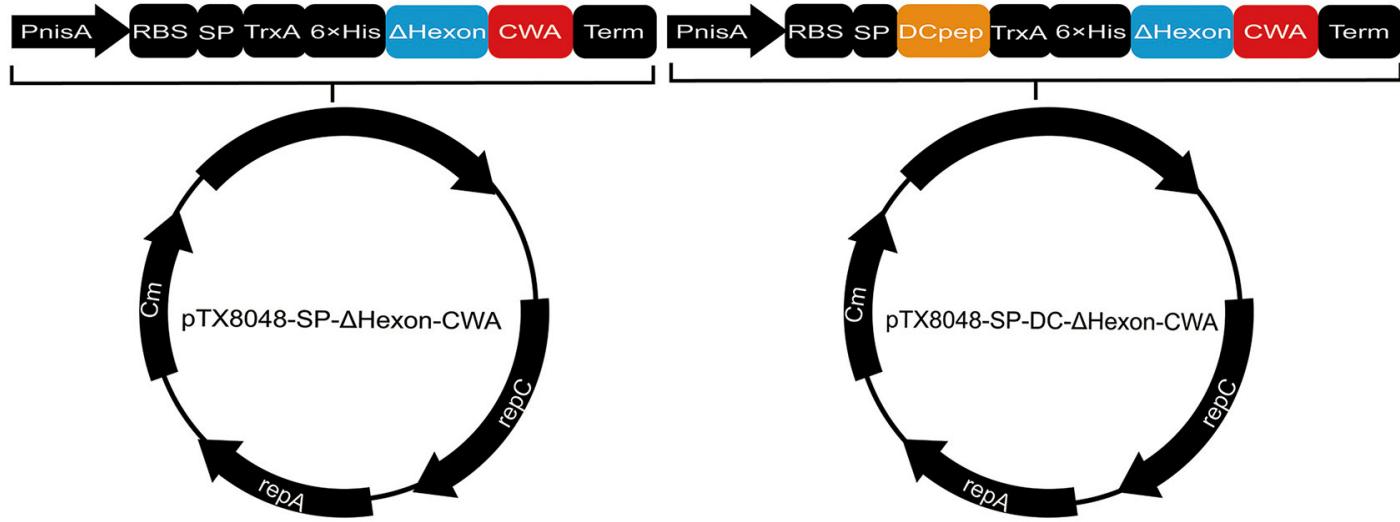

L

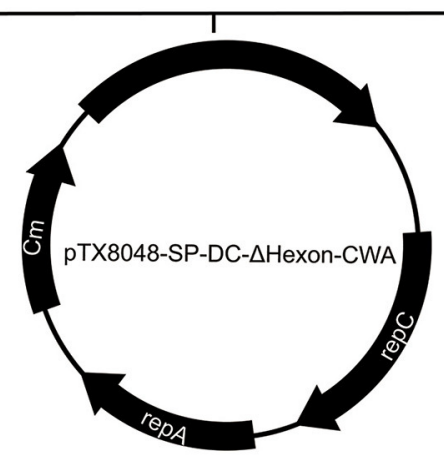

B

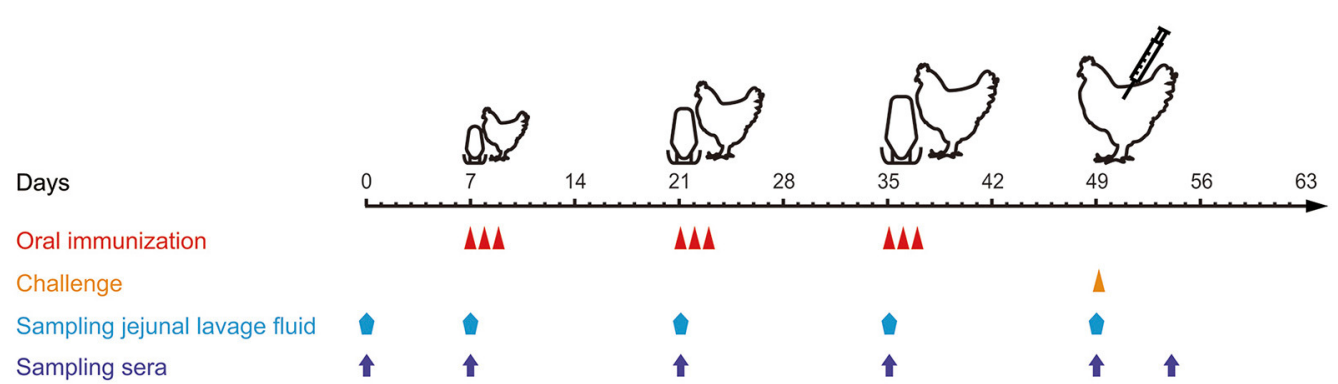

FIGURE 1 | Procedures of immunization, viral challenge, and sampling. (A) Schematic diagram of the recombinant plasmids pTX8048-SP- $\triangle$ Hexon-CWA and PTX8048-SP-DC- $\triangle$ Hexon-CWA. (B) The immunization procedures and sampling schedules. Chickens were immunized with the constructed $\Delta$ Hexon-expressing bacteria three times at 2-week intervals and experimentally challenged with hypervirulent FAdV-4/GX01 strain on day 14 post the third immunization.

\section{Oral Immunization and Challenge Experiment}

Animal grouping, immunizations, and challenges were displayed in Supplementary Table 1. A total of three immunizations were performed at 2-weeks intervals (Figure 1B). Tissue samples of liver, spleen, and heart were collected, and sera and jejunal lavage fluid were prepared from five chickens randomly selected in each group at each time point (Figure 1B). The jejunum tissue $(10 \mathrm{~cm}$ in length) from chicken in each group was flushed twice with a total of $5 \mathrm{ml}$ of cold PBS ( $\mathrm{pH}$ 7.2) containg final concentration of $1 \mathrm{mM}$ PMSF (Solarbio). Then the collected jejunal lavage fluid was centrifuged at $800 \times \mathrm{g}$ for $10 \mathrm{~min}$ at $4^{\circ} \mathrm{C}$, and the supernatants were harvested and stored at $-80^{\circ} \mathrm{C}$ until assays. On day 14 after the third immunizations, all chickens except those in PBS control group were challenged with FAdV-4/GX01 (200 $\mu \mathrm{L}$, containing $10^{5.2} \mathrm{ELD}_{50}$ ) (Supplementary Table 1).

\section{Humoral Immune Responses}

The levels of specific IgG in sera and sIgA in jejunal lavage fluid were detected by indirect ELISA as previously described (24). Briefly, $\Delta$ Hexon protein $(1 \mathrm{mg} / \mathrm{mL})$ was coated on the 96-well plate (100 $\mu \mathrm{L}$ per well). The prepared sera diluted at 1:50 and jejunal lavage fluid diluted at 1:10 were added, respectively, and incubated at $37^{\circ} \mathrm{C}$ for $1 \mathrm{~h}$. HRP-conjugated goat anti-chicken IgG or goat anti-chicken IgA (Abcam, USA) were used as secondary antibodies, respectively. $100 \mu \mathrm{L}$ of ophenylenediamine $(1 \mathrm{mg} / \mathrm{mL})$ and $0.01 \% \mathrm{H}_{2} \mathrm{O}_{2}$ were added to each well, and the reaction was stopped by $2 \mathrm{M} \mathrm{H}_{2} \mathrm{SO}_{4}$. The absorbance was measured at $490 \mathrm{~nm}$ using a reader (Bio-Rad, USA). Each sample was tested in triplicate.

\section{Cytokine Levels in Spleen}

On day 14 after the third immunization, the levels of chicken IL-2 (ChIL-2), chicken interferon-gamma (ChIFN- $\gamma)$, chicken IL-4 (ChIL-4), and chicken IL-10 (ChIL-10) in spleens of all euthanized chickens were detected by quantitative real-time PCR (qPCR). Briefly, total RNA was extracted from spleen using Trizol reagent (Invitrogen, Carlsbad, CA). cDNA was synthesized from $1 \mu \mathrm{g}$ of total RNA using Prime Script RT reagent Kit (TaKaRa Biotech Corp., Dalian, China) according to manufacturer's instructions. qPCR was carried out using SYBR $^{\circledR}$ Premix Ex Taq ${ }^{\mathrm{TM}}$ II (Tli RNase H Plus) (TaKaRa Biotech Corp., Dalian, China). qPCR was performed following the minimum information for publication of quantitative realtime PCR experiments (MIQE) guidelines (36). $\beta$-actin was used as a reference gene for normalization. Primers pairs used in the present study are listed in Table 2. For each 100-fold diluted cDNA sample, amplification efficiencies of all target genes and the reference gene were similar, and the $2^{-\Delta \Delta C t}$ method was used to analyze the relative quantification of the target gene (37).

\section{Lymphocyte Proliferation in Peripheral Blood}

To determine the proliferation of peripheral blood lymphocytes (PBLs) on day 14 after the final vaccination, peripheral blood of chickens in each group $(n=5)$ was collected 
A

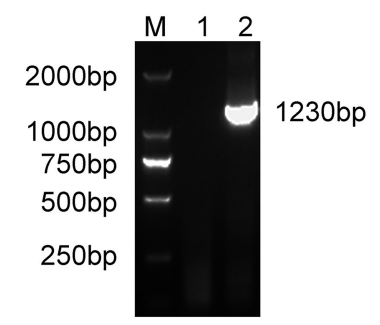

C

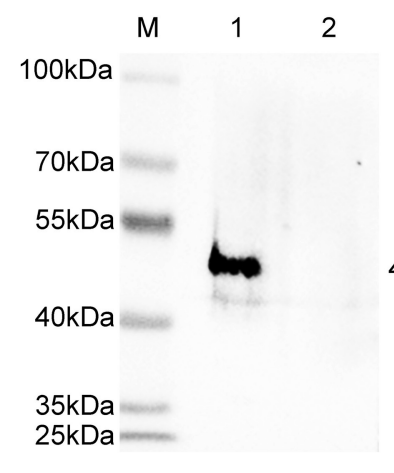

B

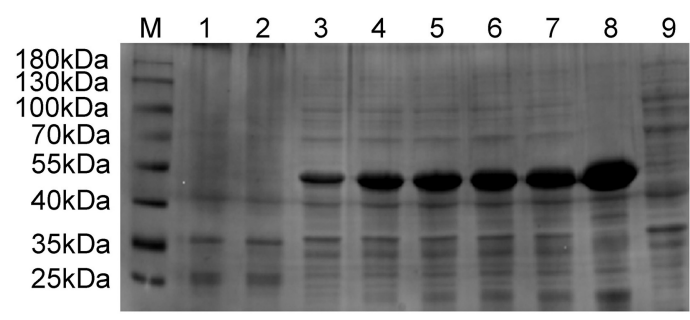

D

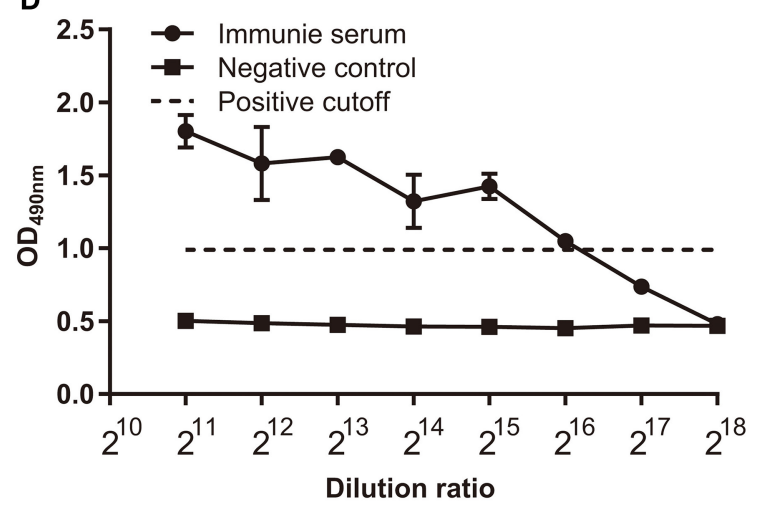

FIGURE 2 | Characterization of polyclonal antisera against $\triangle$ Hexon protein of FAdV. (A) Identification of recombinant plasmid pET30(a)- $\Delta$ Hexon by PCR. Lane M, DL 2000 DNA Marker; Lane 1, Negative control; Lane 2, Identification of pET30(a)- $\Delta$ Hexon by PCR. (B) SDS-PAGE analysis of expressed $\Delta$ Hexon protein in E. coli. Lane M, protein molecular weight marker (Thermo Scientific ${ }^{\mathrm{TM}}$ ); Lane 1, Proteins in recombinant bacteria E. coli BL21/pET30a; Lane 2, Proteins in recombinant bacteria E. coli BL21/pET30a- $\Delta$ Hexon without induction by Isopropyl $\beta$-D- Thiogalactopyranoside (IPTG); Lane 3-7, Proteins in recombinant bacterial E. coli

BL21/pET30a- $\Delta$ Hexon induced by IPTG for 1, 2, 4, 5, 6 h; Lane 8, Cell pellet of sonicated recombinant bacteria $E$. coli BL21/pET30a- $\Delta$ Hexon induced by IPTG for $7 \mathrm{~h}$; Lane 9, Cell supernatant of sonicated recombinant bacteria E. coli BL21/pET30a- $\Delta$ Hexon induced by IPTG for $7 \mathrm{~h}$. (C) Purified $\Delta$ Hexon proteins were separated by SDS-PAGE, transferred to nitrocellulose membranes, and probed with prepared rabbit anti- $\Delta$ Hexon polyclonal sera. The expected bands were observed. Lane M, protein molecular weight marker (Thermo Scientific ${ }^{\text {TM}}$ ). Lane 1, $\Delta$ Hexon protein from E. coli BL21/pET30a- $\Delta$ Hexon; Lane 2, protein from E. coli BL21/pET30a.

(D) Enzyme linked immunosorbent assay (ELISA) was used to determine titers of rabbit anti- $\Delta$ Hexon polyclonal antisera. $100 \mu \mathrm{L}$ of recombinant $\Delta$ Hexon protein $(10 \mu \mathrm{g} / \mathrm{mL})$ was coated. The prepared sera were diluted in 2-fold series and added into each well. The prepared sera from chickens before immunization was used as the negative control. The cut off value was 2.1 times of the $\mathrm{OD}_{490}$ value of the negative control, the titer of prepared rabbit anti- $\Delta$ Hexon polyclonal sera determined by ELISA was $1: 2^{16}$.

via wing vein, and PBLs were isolated using lymphocyte separation medium (1.077 g/mL) (Tianjin Haoyang Biological Manufacture, China). The isolated cells were modulated to a final concentration of $5 \times 10^{6}$ cells $/ \mathrm{mL}$. The proliferation of PBLs were determined with the Cell Counting Kit-8 solution (CCK-8, Bimake). Briefly, cell suspension containing RPMI 1640 medium supplemented with $10 \%$ fetal bovine sera was added into a 96-well plate $(100 \mu \mathrm{L}$ per well) with eight duplicates and incubated at $37^{\circ} \mathrm{C}$ for $24 \mathrm{~h}$ in a $5 \% \mathrm{CO}_{2}$ incubator. Cells were stimulated with $5 \mu \mathrm{g} / \mathrm{mL}$ of recombinant $\Delta$ Hexon protein for $48 \mathrm{~h}$, then $10 \mu \mathrm{L}$ of Cell Counting Kit8 solution (CCK-8, Bimake) was added into each well to incubate at $37^{\circ} \mathrm{C}$ for another $4 \mathrm{~h}$. The CellTiter $96^{\circledR}$ AQueous Non-Radioactive Cell Proliferation Assay (Promega, Fitchburg, WI, USA) was evaluated according to the manufacturer's instructions. The value of $\mathrm{OD}_{490 \mathrm{~nm}}$ in each well was measured. Each sample was tested in triplicate. Cells stimulated with $5 \mu \mathrm{g} / \mathrm{mL}$ of concanavalin A (ConA, Sigma) or incubated with cell culture medium was used as a positive and negative control, respectively.

\section{Detection of Hepatic Function and Viral Load in Liver}

The levels of aspartate transaminase (AST), alanine transaminase (ALT), albumin (ALB), total protein (TP), and lactate dehydrogenase $(\mathrm{LDH})$ in sera were determined using the corresponding detection kit (Jiancheng Biological Engineering Institute, Nanjing, Jiangsu) according to the manufacturer's protocol. Each sample was detected in triplicate. DNA of FAdV was extracted by TaKaRa MiniBEST Viral RNA/DNA Extraction Kit Ver.5.0 (Takara, Beijing, China), and the virus load in liver was quantified using qRT-PCR as previously described (33). The primer pair 52K-F/52K-R are listed in Table 2.

\section{Necropsy and Histopathology}

All the birds were euthanized and necropsied. Several organs, including hearts, livers, spleens, and kidneys, were collected for recording gross pathological changes on 5 days past infection (dpi). The above-collected samples were immersed in $10 \%$ neutral buffered formalin, embedded in paraffin, sectioned, and stained with hematoxylin-eosin (HE). The histopathological 


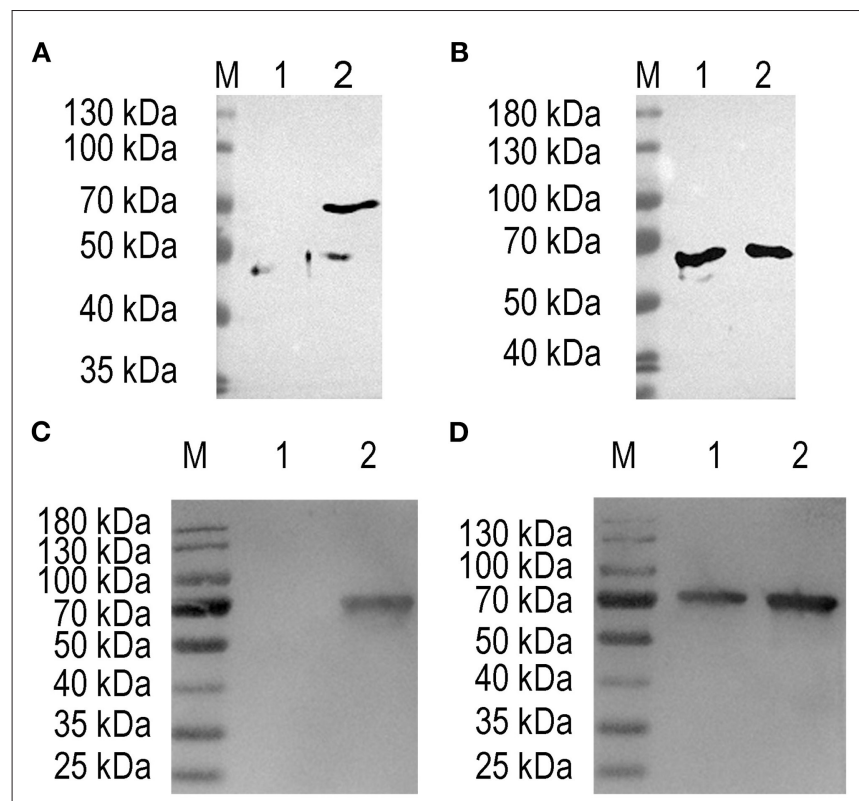

FIGURE 3 | Detection of $\Delta$ Hexon protein expressed in Lactococcus lactis and Enterococcus faecalis using western blot. Proteins from $\Delta$ Hexon-expressing $L$. lactis or $\Delta$ Hexon-expressing $E$. faecalis was separated by SDS-PAGE, transferred to nitrocellulose membranes, then reacted with polyclonal antisera against $\Delta$ Hexon protein. (A) Detection of $\Delta$ Hexon protein in

NZ9000/pTX8048-SP- $\Delta$ Hexon-CWA. Lane M, protein molecular weight prestained marker (Thermo Scientific ${ }^{\mathrm{TM}}$ ); Lane 1, $\Delta$ Hexon protein in NZ9000/pTX8048-SP- $\Delta$ Hexon-CWA without induction by nisin (Sigma-Aldrich); Lane 2, $\Delta$ Hexon protein $(70 \mathrm{kDa})$ from

NZ9000/pTX8048-SP- $\Delta$ Hexon-CWA induced by $5 \mathrm{ng} / \mathrm{mL}$ nisin

(Sigma-Aldrich). (B) Detection of $\Delta$ Hexon protein in MDXEF-1/ $\Delta$ Hexon-CWA Lane M, Protein molecular weight prestained marker (Thermo Scientific ${ }^{\mathrm{TM}}$ );

Lane 1, $\Delta$ Hexon protein $(70 \mathrm{kDa}$ ) in MDXEF-1/ $\Delta$ Hexon-CWA without induction by nisin (Sigma-Aldrich); Lane 2, $\Delta$ Hexon protein $(70 \mathrm{kDa})$ in MDXEF-1/ $\Delta$ Hexon-CWA induced by $5 \mathrm{ng} / \mathrm{mL}$ nisin (Sigma-Aldrich). (C) Detection of $\Delta$ Hexon protein in NZ9000/DC- $\Delta$ Hexon-CWA. Lane M, protein molecular weight prestained marker (Thermo Scientific ${ }^{\mathrm{TM}}$ ); Lane 1, $\Delta$ Hexon protein in MDXEF-1/ $\Delta$ Hexon-CWA protein without induction by nisin (Sigma-Aldrich); Lane 2, $\Delta$ Hexon protein $(72 \mathrm{kDa})$ in

NZ9000/DC- $\Delta$ Hexon-CWA induced by $5 \mathrm{ng} / \mathrm{mL}$ nisin (Sigma-Aldrich). (D) Detection of $\Delta$ Hexon protein $(72 \mathrm{kDa}$ ) in MDXEF-1/DC- $\Delta$ Hexon-CWA without induction by nisin (Sigma-Aldrich). Lane M, protein molecular weight prestained marker (Thermo Scientific ${ }^{\mathrm{TM}}$ ). Lane $1, \Delta$ Hexon protein $(72 \mathrm{kDa})$ in MDXEF-1/DC- $\Delta$ Hexon-CWA without induction by nisin (Sigma-Aldrich). Lane 2, $\Delta$ Hexon protein $(72 \mathrm{kDa}$ ) in MDXEF-1/DC- $\Delta$ Hexon-CWA induced by $5 \mathrm{ng} / \mathrm{mL}$ nisin (Sigma-Aldrich).

changes in the prepared slides were observed using a light microscope (Nikon, EX200).

\section{Statistical Analysis}

SPSS24 (SPSS/IBM, Chicago, IL, USA) and Prism7.0 (GraphPad Software, La Jolla, CA, USA) was used for one-way ANOVA and Duncan's multiple-comparison procedures of the data. All data are expressed as mean \pm standard deviation (SD). A $p$-value of $<0.05$ is considered to be statistically significant, and a $p$-value of $<0.01$ is considered to be highly significant.

\section{RESULTS}

\section{Production of Polyclonal Antisera Against $\Delta$ Hexon Protein}

Identification of recombinant plasmid pET30(a)- $\Delta$ Hexon by PCR showed an expected fragment of 1230 bp (Figure 2A). The FAdV-4 $\Delta$ Hexon protein (from 10 to 420 aa) was expressed in E. coli. BL21, and SDS-PAGE displayed a protein band of $\sim 50 \mathrm{kDa}$ (Figure 2B), which showed positive immunoreaction with rabbit anti- $\Delta$ Hexon sera in western blot assays (Figure 2C). The titer of the prepared rabbit anti- $\Delta$ Hexon protein polyclonal antisera was 1:2 ${ }^{16}$ (Figure 2D).

\section{Expression of $\Delta$ Hexon Protein in L. lactis NZ9000 and E. faecalis}

The target fragment of $1,230 \mathrm{bp}$ was released from plasmid pTX8048-SP- $\triangle$ Hexon-CWA and pTX8048-SP-DC- $\Delta$ HexonCWA upon digestion with BamH I and Kpn I, respectively. All the positive plasmids were further sequenced. The positive plasmids were electroporated into L. lactis NZ9000 and E. faecalis MDXEF-1, respectively, and the positive bacteria NZ9000/pTX8048-SP- $\Delta$ Hexon-CWA, NZ9000/pTX8048-SPDC- $\Delta$ Hexon-CWA, MDXEF-1/pTX8048-SP- $\Delta$ Hexon-CWA, and MDXEF-1/pTX8048-SP-DC- $\Delta$ Hexon-CWA were identified. The cell wall-anchored $\Delta$ Hexon protein $(70 \mathrm{kDa})$ fusion or without fusion with DC targeting peptide in L. lactis NZ9000 (Figures 3A,C) and E. faecalis MDXEF-1 (Figures 3B,D) were detected by western blot. The results from indirect immunofluorescence assay (IFA) showed that fluorescence on the surface of recombinant bacteria NZ9000/ $\Delta$ HexonCWA and MDXEF-1/ $\triangle$ Hexon-CWA (Figures 4B,E), NZ9000/DC- $\Delta$ Hexon-CWA and MDXEF-1/DC- $\Delta$ Hexon-CWA (Figures 4C,F) were observed.

\section{Humoral Immune Responses Induced by $\Delta$ Hexon-Expressing Bacteria}

On day 14 post each immunization, the levels of both Hexonspecific sera IgG (Figure 5A) and sIgA in jejunal lavage fluid (Figure 5B) from chickens in the four groups NZ9000/ $\Delta$ HexonCWA, NZ9000/DC- $\Delta$ Hexon-CWA, MDXEF- $1 / \Delta$ Hexon-CWA, and MDXEF-1/DC- $\triangle$ Hexon-CWA were significantly higher than that in the groups NZ9000/pTX8048, MDXEF-1/pTX8048 and PBS $(p<0.01)$. Notably, the levels of specific IgG and sIgA in the two groups NZ9000/DC- $\triangle$ Hexon-CWA and MDXEF$1 / \mathrm{DC}-\Delta$ Hexon-CWA were significantly higher than that in the groups NZ9000/ $\Delta$ Hexon-CWA and MDXEF- $1 / \Delta$ Hexon-CWA $(p<0.01)$. The results displayed that introduction of DCpep (DC- $\Delta$ Hexon-CWA) stimulated more robust humoral immune responses than $\triangle$ Hexon-CWA.

\section{mRNA Expression of Cytokines in Spleen}

The mRNA levels of ChIL-2, ChIFN- $\gamma$, ChIL-4, and ChIL-10 (Figures 6A,B) in spleens of chickens immunized with four $\Delta$ Hexon-expressing bacteria were significantly higher than of chickens in PBS and empty vector control groups on days 14 post-third immunizations $(p<0.01)$. Moreover, the mRNA 
A

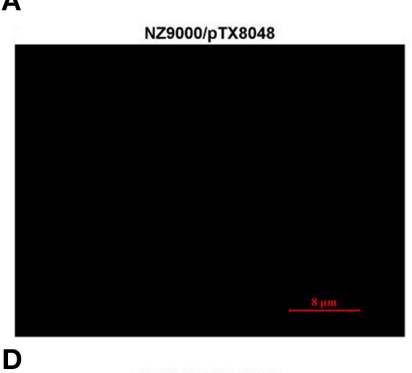

D

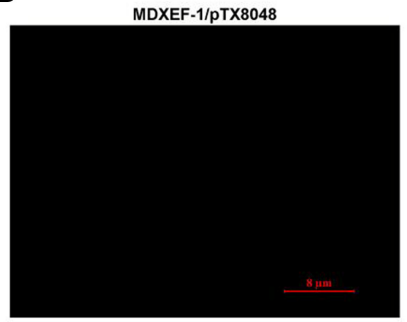

B

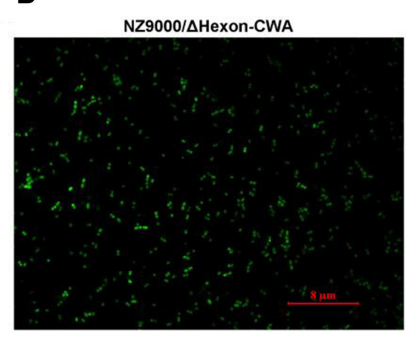

E

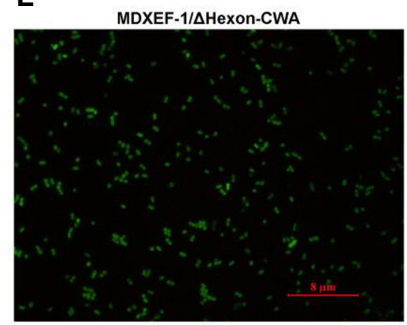

C

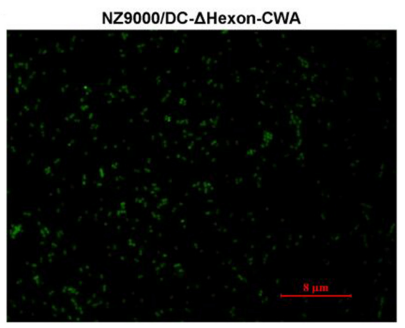

$\mathbf{F}$

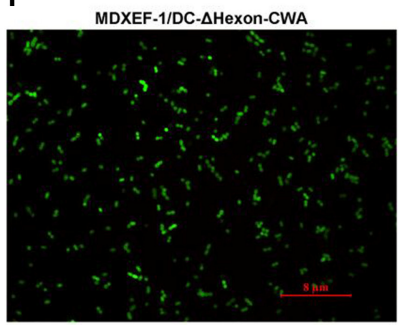

FIGURE 4 | Detection of $\Delta$ Hexon protein expressed on the surface of recombinant Lactococcus lactis NZ9000 and Enterococcus faecalis MDXEF-1 by indirect immunofluorescence assay (IFA). The recombinant $L$. lactis and $E$. faecalis induced by $5 \mathrm{ng} / \mathrm{mL}$ nisin (Sigma-Aldrich) were washed and centrifuged. The pellets were incubated with rabbit polyclonal antisera against $\Delta$ Hexon, then reacted with goat anti-rabbit lgG conjugated to fluorescein isothiocyanate (FITC). The fluorescence on the surface of recombinant bacteria NZ9000/ $\Delta$ Hexon-CWA and MDXEF-1/ $\Delta$ Hexon-CWA (B,E), NZ9000/DC- $\Delta$ Hexon-CWA and MDXEF-1/DC- $\Delta$ Hexon-CWA (C,F) were observed. Recombinant bacteria NZ9000/pTX80488 (31) (A) and MDXEF-1/pTX8048 (25) (D) were used as negative controls.

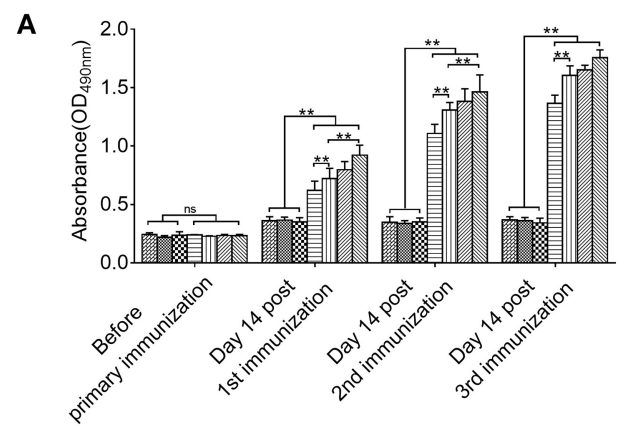

Serum IgG levels of immunized chickens

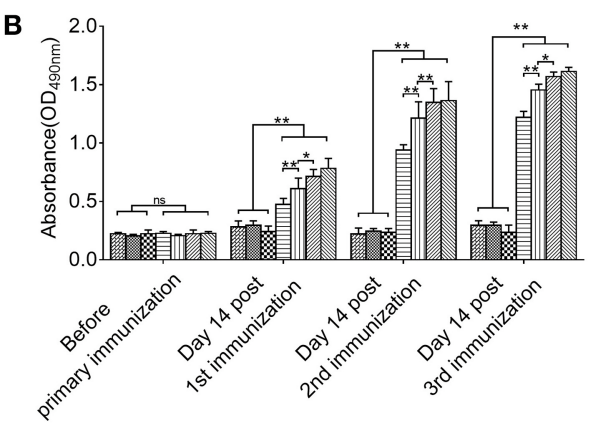

IgA levels in jejunal lavage fluid of chickens
图 PBS Control

NZ9000/pTX8048

娄 MDXEF-1/pTX8048

目 NZ9000/pTX8048-SP- $\triangle$ Hexon-CWA

四 NZ9000/pTX8048-SP-DC- $\Delta$ Hexon-CWA

MDXEF-1/pTX8048-SP- $\triangle$ Hexon-CWA

$\mathbb{Q}$ MDXEF-1/pTX8048-SP-DC- $\Delta$ Hexon-CWA

FIGURE 5 | Detection of $\Delta$ Hexon-specific lgG antibody levels in sera (A) and $\Delta$ Hexon-specific slgA antibody levels in jejunal lavage fluid (B) from chickens immunized with $\Delta$ Hexon-expressing bacteria in each group. Recombinant $\Delta$ Hexon protein in $E$. coli BL21 (10 $\mu \mathrm{g} / \mathrm{mL})$ was coated (100 $\mu \mathrm{L}$ per well). On day 14 post each immunization, ELISA method was used to determine the lgG levels in sera $(\mathbf{A})$ and slgA levels in jejunal lavage fluid $(\mathbf{B})$. The values represent mean \pm SD $(n=5)$. ${ }^{*} p<0.05,{ }^{* *} p<0.01$.

levels of ChIL-2, ChIFN- $\gamma$, ChIL-4, and ChIL-10 in MDXEF$1 / \Delta$ Hexon-CWA and MDXEF-1/DC- $\Delta$ Hexon-CWA group were significantly higher than that in NZ9000/ $\triangle$ Hexon-CWA, and NZ9000/DC- $\Delta$ Hexon-CWA group, respectively $(p<0.01)$.

\section{Lymphocytes Proliferation Responses}

On days 14 after three immunizations, PBLs from chickens immunized with four $\Delta$ Hexon-expressing bacteria showed significant specific responses to recombinant $\Delta$ Hexon protein compared with that from chickens immunized with the NZ9000/pTX8048, MDXEF-1/pTX8048, and PBS (pH7.2) $(p<0.01)$. However, proliferation responses of PBLs to ConA between any other two groups showed no statistical difference $(p>0.05 ;$ Figure 6C). Proliferation responses of PBLs to $\triangle$ Hexon protein in MDXEF-1/DC- $\triangle$ Hexon-CWA and NZ9000/DC- $\triangle$ Hexon-CWA group were higher than that in

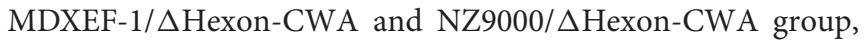
respectively $(p<0.01)$. Notably, proliferation responses of PBLs to $\triangle$ Hexon protein in the two groups immunized with $\Delta$ Hexon-expressing $E$. faecalis were higher than those in the two groups immunized with $\Delta$ Hexon-expressing L. lactis $(p<0.01$; Figure 6C).

\section{Function Indexes and Virus Load in Liver}

Previous studies have shown that the liver function indexes were related to seral TP, ALB, AST, ALT, and LDH, and changed obviously on day 4 post-infection (dpi) (38). On $4 \mathrm{dpi}$, the 


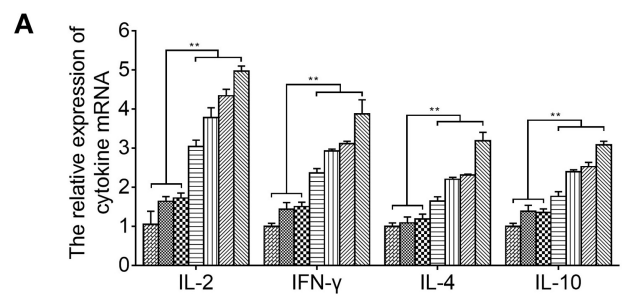

C

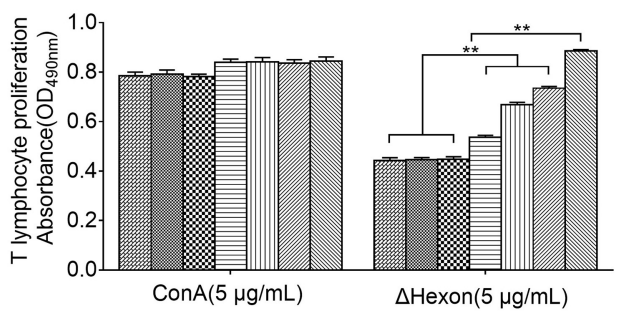

图 PBS Control

NZ9000/pTX8048

田 MDXEF-1/pTX8048

(I) NZ9000/pTX8048-SP-DC- $\Delta$ Hexon-CWA

目 NZ9000/pTX8048-SP- $\triangle$ Hexon-CWA

MDXEF-1/pTX8048-SP- $\triangle$ Hexon-CWA

$\mathbb{N}$ MDXEF-1/pTX8048-SP-DC- $\Delta$ Hexon-CWA

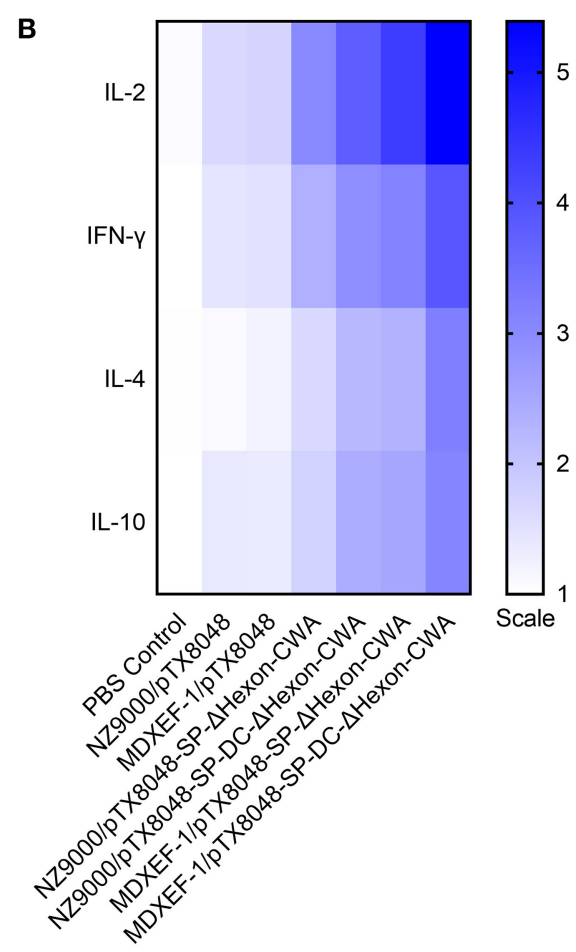

FIGURE 6 | The mRNA expression levels of IL-2, interforn- $\gamma(\mathrm{IFN}-\gamma)$, IL-4, and IL-10 (A,B) in spleens of chickens in each group post-tertiary immunization and the proliferation of PBLs (C). (A) On 2-week post-tertiary immunization, the mRNA expression levels of IL-2, interforn-gamma (IFN- $\gamma$ ), IL-4, and IL-10 in spleens of five chickens in each group was determined by quantitative Real-time PCR (qRT-PCR). The mRNA levels of each chicken in each group were divided by mRNA levels of $\beta$-actin of the same chicken to normalize IL-2, IFN- $\gamma$, IL-4, and IL-10. (B) Heat map of the mRNA expression levels of IL-2, IFN- $\gamma$, IL-4, and IL-10 in chickens spleens. (C) PBLs of chickens $(n=5)$ in each group were isolated on 2-week post the third immunization. The proliferation of lymphocytes stimulated by $\Delta$ Hexon protein or concavanalin (ConA) was detected by Cell Counting Kit-8 (CCK8) assay. Data are expressed as mean \pm SD $(n=5)$. ${ }^{*} p<0.05$, ${ }^{* *} p<0.01$. AST, aspartate transaminase; ALT, alanine transaminase; ALB, albumin; TP, total protein; and LDH, lactate dehydrogenase.

levels of TP, ALB, AST, LDH, and ALT (Figure 7) in sera of chickens immunized with four $\Delta$ Hexon-expressing bacteria showed no statistical differences with chickens in the PBS group. In contrast, significant differences between PBS control group and challenge control group or empty vector control groups (NZ9000/pTX8048 and MDXEF-1/pTX8048) were observed. Specifically, ALB and TP levels in sera of chickens from both challenge control and vector control groups were significantly lower than those in PBS group $(p<0.01)$, while the levels of AST, ALT, and LDH were significantly higher. On $5 \mathrm{dpi}$, the copies of FAdV in livers of chickens in challenged control group $\left(1.2 \times 10^{8}\right.$ copies $/ \mathrm{mg})$ and vector control groups $\left(7.6 \times 10^{7}\right.$ copies $/ \mathrm{mg}$ for NZ9000/pTX8048, $7.0 \times 10^{7}$ copies/mg for MDXEF$1 /$ pTX8048) were significantly higher than that of chickens immunized with the four $\Delta$ Hexon-expressing bacteria $\left(1.3 \times 10^{6}\right.$ copies/mg for NZ9000/ $\mathrm{H}$ Hexon-CWA, $4.1 \times 10^{5}$ copies $/ \mathrm{mg}$ for NZ9000/DC- $\triangle$ Hexon-CWA, $7.6 \times 10^{4}$ copies/mg for MDXEF-1/ $\triangle$ Hexon-CWA and $1.2 \times 10^{4}$ copies/mg for MDXEF$1 /$ DC- $\Delta$ Hexon-CWA $)(p<0.01)$. Meanwhile, significant differences were observed between groups NZ9000/ $\Delta$ HexonCWA and NZ9000/DC- $\triangle$ Hexon-CWA, and between MDXEF-1/AHexon-CWA and MDXEF-1/DC- $\Delta$ Hexon-CWA (Figure 7F).

\section{Mortality}

On $3 \mathrm{dpi}$, chickens in the challenged control group and vector control groups (NZ9000/pTX8048, MDXEF-1/pTX8048) were depressed and gradually dead showing $100 \%$ mortality on 5 dpi. Birds in the four groups immunized with $\Delta$ Hexon-expressing bacteria were partially protected against FAdV challenge in $100 \%$ lethal dose (Figure 8), displaying the survival rates of 50,60, $80,90 \%$ for the group NZ9000/ $\triangle$ Hexon-CWA, NZ9000/DC$\triangle$ Hexon-CWA, MDXEF-1/ $\triangle$ Hexon-CWA, and MDXEF-1/DC$\triangle$ Hexon-CWA, respectively. Notably, the time of death for challenged chickens in the group MDXEF-1/ $\triangle$ Hexon-CWA and MDXEF-1/DC- $\triangle$ Hexon-CWA was obviously delayed compared to other immunized groups, indicating live recombinant bacteria MDXEF-1/ $\Delta$ Hexon-CWA and MDXEF-1/DC- $\Delta$ Hexon-CWA exhibited more protective efficacy against FAdV challenge than the live recombinant bacteria NZ9000/ $\triangle$ Hexon-CWA and NZ9000/DC- $\triangle$ Hexon-CWA.

\section{Pathological Lesions}

The typical gross lesions of HPS were observed after challenging with a lethal dose of FAdV-4/GX01, showing by typical gross lesions, including hydropericardium, splenomegaly, hepatomegaly, and nephritis during autopsy of challenged 
A

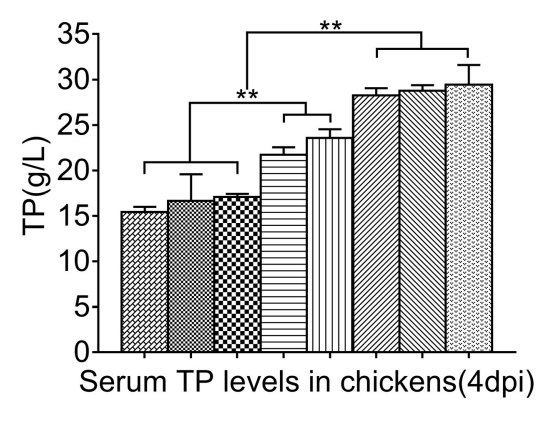

C

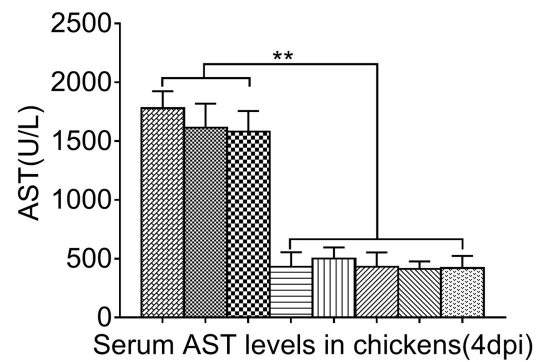

E

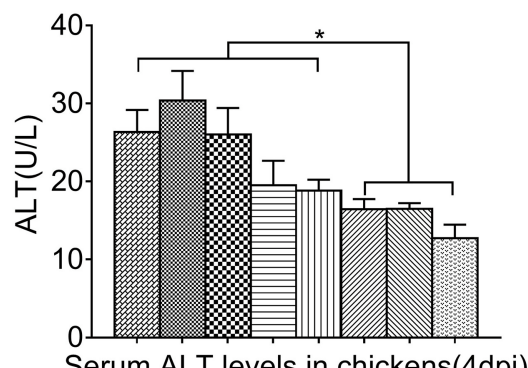

Serum ALT levels in chickens(4dpi)
B

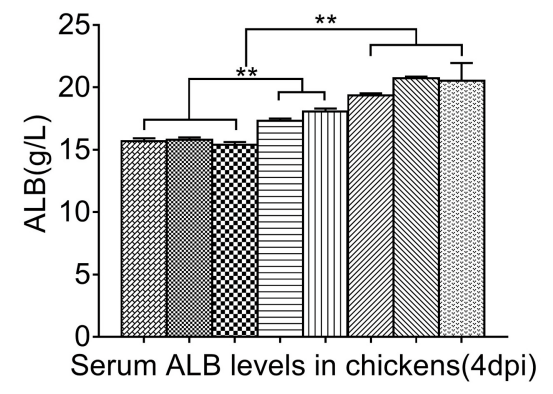

D

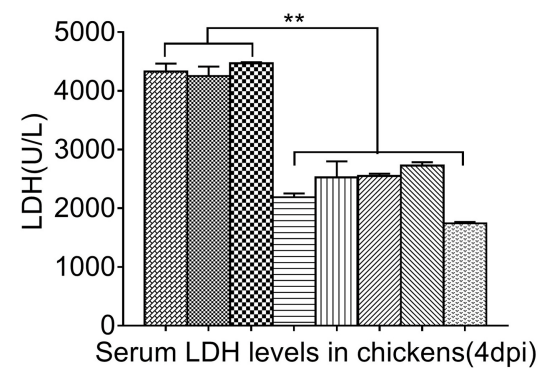

$\mathbf{F}$

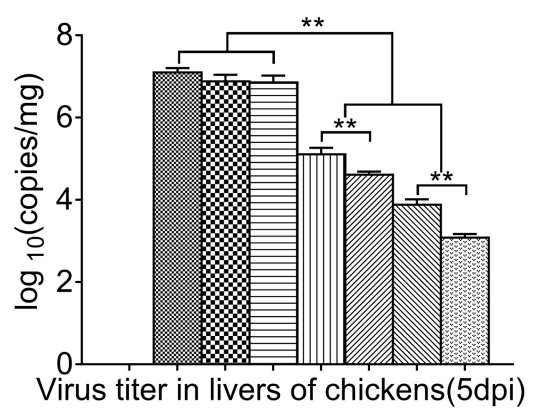

PBS Control

NZ9000/pTX8048

MDXEF-1/pTX8048

NZ9000/pTX8048-SP- $\triangle$ Hexon-CWA

NZ9000/pTX8048-SP-DC- $\triangle$ Hexon-CWA

MDXEF-1/pTX8048-SP- $\triangle$ Hexon-CWA

MDXEF-1/pTX8048-SP-DC- $\Delta$ Hexon-CWA

Infection Control

FIGURE 7 | Levels of total protein (TP) (A), albumin (ALB) (B), aspartate transaminase (AST) (C), lactate dehydrogenase (LDH) (D), alanine transaminase (ALT) (E) in sera, and copies of FAdV (F) in livers of chickens challenged with FAdV-4/GX01. On 4 dpi, the levels of TP (A), ALB (B), AST (C), LDH (D), ALT (E) in sera of chickens from each group were detected using a Detection Kit (Jiancheng Bioengineering Institute, Nanjing, China) according to the manufacturer's protocol. (F) On 5 dpi, liver samples from chickens in each group were collected. Total DNA was extracted using TaKaRa MiniBEST Viral RNA/DNA Extraction Kit Ver.5.0 (Takara, Beijing, China). qRT-PCR was applied to detect copies of FAdV DNA in samples. Each value represents mean $\pm \operatorname{SD}(n=5) .{ }^{*} p<0.05,{ }^{* *} p<0.01$.

chickens in each Group (Supplementary Figure 1). Of note, chickens from the four groups immunized with live recombinant $\triangle$ Hexon-expressing bacteria presented mild HPS, and the gross pathological lesions in hearts, spleens, livers, and renals were also moderate. The typical histopathological changes of HPS were presented by the myocardial fiber fracture and even dissolution, lymphocytic myocarditis, degeneration and even necrosis of renal tubular epithelium, and severe necrosis disintegration of splenic lymphocytes. However, chickens from the four groups immunized with $\Delta$ Hexon-expressing bacteria, especially the group vaccinated with MDXEF-1/DC- $\Delta$ Hexon-CWA, displayed mild histopathological changes (Figure 9).

\section{DISCUSSION}

The structural proteins of FAdV-4 contain Fiber 1, Fiber 2, Penton, and Hexon $(39,40)$. The subunit vaccines based on Penton and Fiber 2 were recorded to induce immunoprotection 


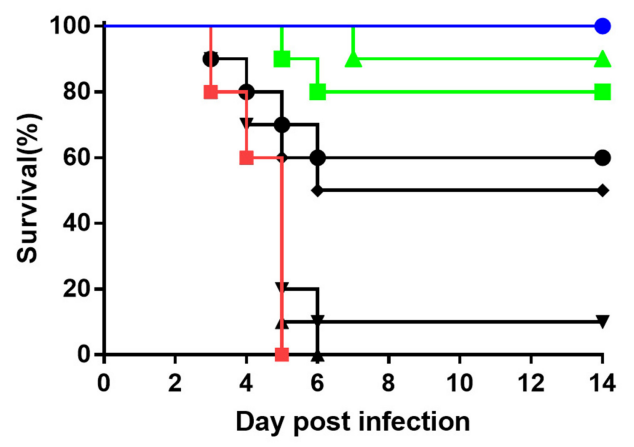

PBS Control

- Infection Control

NZ9000/pTX8048

- MDXEF-1/pTX8048

$\rightarrow$ NZ9000/AHexon-CWA

- NZ9000/DC- $\triangle$ Hexon-CWA

- MDXEF- $1 / \Delta$ Hexon-CWA

$₫$ MDXEF-1/DC- $\triangle$ Hexon-CWA

FIGURE 8 | Survival ratios of chickens to challenge of virulent FAdV-4/GX01 in each immunized group. After challenging with virulent FAdV-4/GX01, 90-100\% of chickens in the groups were immunized with NZ9000/pTX8048, MDXEF-1/pTX8048, and PBS died. The survival ratio of 50,60, 80, 90\% were observed in chickens

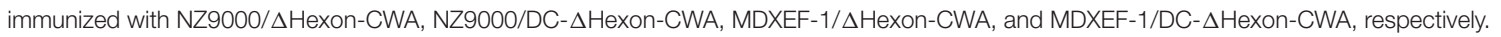

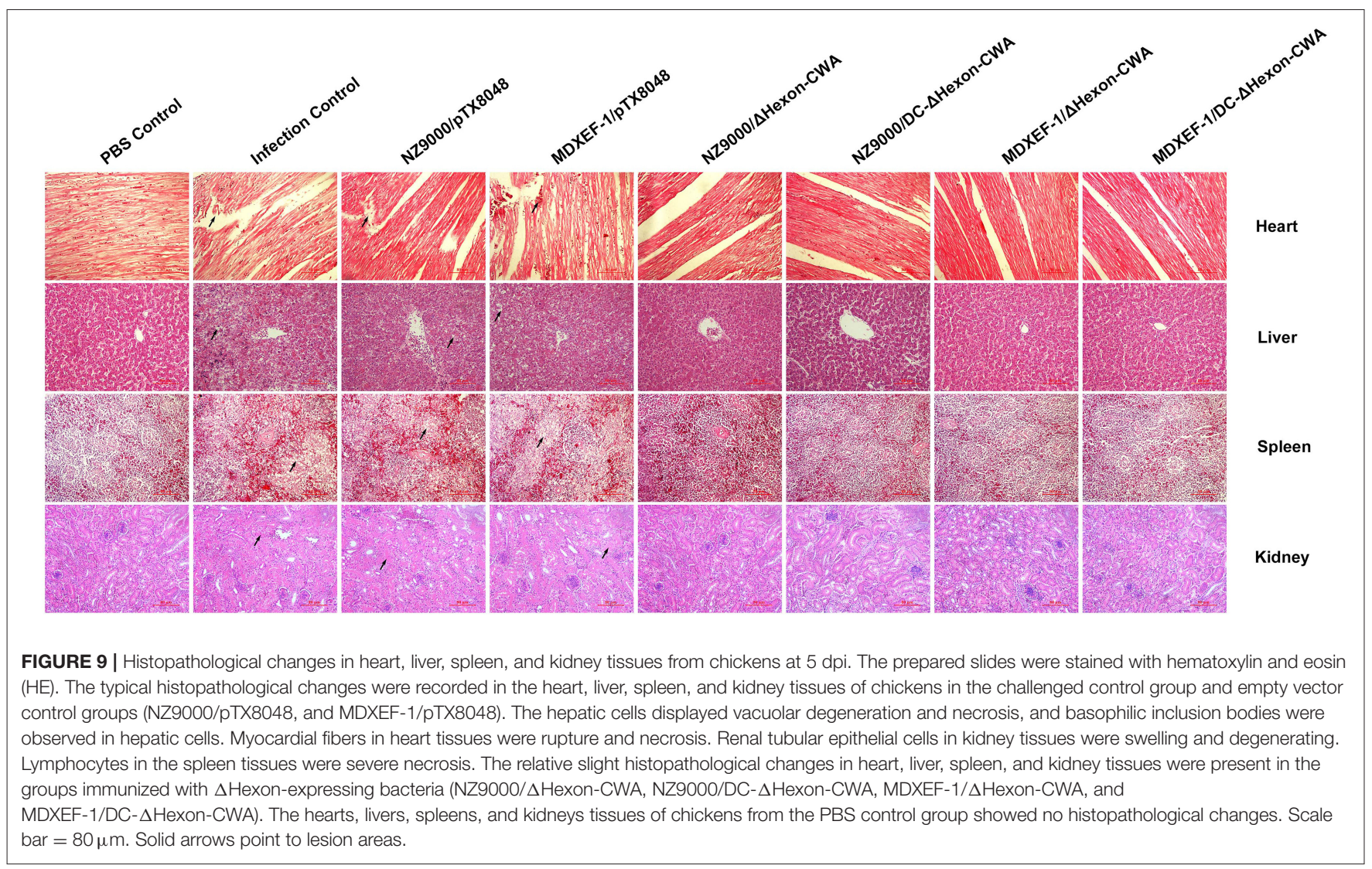

against FAdV infection in chickens (22). However, the immune protection and immune mechanism of the vaccine based on Hexon protein was not reported until now. Hexon protein, one of the most important structural proteins on the surface of adenovirus, contains the type-, group- and subclass-specific antigenic determinants that can stimulate the body to produce efficient neutralizing antibodies. In the present study, the truncated Hexon protein $(\Delta$ Hexon) of the current epidemic
FAdV-4 strain (isolated and stored in our lab) spanning amino acids from 10 to 420 was chosen, in which loop1, loop2, and P1 were contained. Prediction using molecular software DNAstar Lasergene 7.1 (DNAS Inc., Madison, WI, USA) showed that $\Delta$ Hexon displays high antigenicity. Meanwhile, $\Delta$ Hexon protein was fused to dentritic cell (DC) targeting peptide (DC- $\Delta$ Hexon) $(21,41)$ with the aim of enhancing $\Delta$ Hexonspecific immune responses. Then fusion protein DC- $\Delta$ Hexon 
was inserted into expressing vector (31) in which cell wallanchored (CWA) sequences were contained to display target fusion protein on the surface of recombinant L. lactis and E. faecalis $(25,31)$.

The results of vaccinations suggested that all four recombinant $\Delta$ Hexon-expressing bacteria elicited a higher level of sera IgG and sIgA in jejunal lavage compared to the empty control group $(p<0.01)$, demonstrating that humoral immune responses of immunized chicken were effectively evoked. Moreover, cell wall-anchored $\Delta$ Hexon protein fused by DC targeting peptide (DCpep) induced higher sIgA levels in jejunal lavage than cell wall-anchored $\Delta$ Hexon delivered by $L$. lactis and E. faecalis $(p<0.05)$, which indicating that introduction of DCpep on the surface of bacteria effectively targeted intestinal dendritic cells to enhance antigenic uptake and the subsequent delivery to immune cells. The above results were consistent with our previous report by $\mathrm{Ma}$ et al. (31). In addition, live recombinant bacteria MDXEF- $1 / \triangle$ Hexon-CWA and MDXEF$1 / \mathrm{DC}-\triangle$ Hexon-CWA induced more robust immune responses and provided more protective effects than NZ9000/ $\triangle$ HexonCWA and NZ9000/DC- $\Delta$ Hexon-CWA, respectively $(p<0.05)$. The possible explanations for this result may be that $E$. faecalis was isolated from ceca and partially colonized in ceca (data not published), and live recombinant $\Delta$ Hexonexpressing sustainably stimulated $\Delta$ Hexon-specific immune responses. Meanwhile, $\Delta$ Hexon-CWA, or DC- $\Delta$ Hexon-CWA protein in recombinant $\Delta$ Hexon-expressing $E$. faecalis could be detected without induction of nisin, which suggests that host bacteria $E$. faecalis MDXEF-1 probably produce nisin or nisin-like substance that continuously induced expression of the target protein. This prediction remains to be further studied and proved in our subsequent research. Previous study has demonstrated that adenovirus settles in the intestinal epithelium at $12 \mathrm{~h}$ post-infection via oral route, and the virus can be detected in blood as early as $24 \mathrm{~h}$ post-infection (42). The significantly higher levels of Hexon-specific IgG could bind to FAdV in sera to form complexes that could be more easily engulfed by macrophages. The higher levels of sIgA in jejunal lavage can bind to FAdV located at local intestinal epithelium and intercept virus invasion upon initial infection. Therefore, chickens vaccinated with the four recombinant bacteria expressing anchored $\Delta$ Hexon protein, especially those carrying DCpep bacteria, induced more effective systemic humoral immune responses and protection against FAdV infection.

As for cellular immune responses, in the present study, the proliferation response of PBLs was more efficient in the groups immunized with four $\Delta$ Hexon-expressing bacteria. Moreover, mRNA levels of ChIL-2, ChIFN- $\gamma$, and ChIL4, ChIL-10 in spleens of chickens immunized with four $\Delta$ Hexon-expressing bacteria were significantly upregulated, suggesting that both the Th1 and Th2 type responses were enhanced to resist virus infection. The present results could support the above analysis that on day 5 post-infection (dpi), the number of FAdV copies in livers of chickens from NZ9000/pTX8048 and MDXEF-1/pTX8048 group was significantly higher than that in the four $\Delta$ Hexon-expressing bacteria groups, especially the two groups of $\Delta$ Hexon-expressing E. faecalis.

The average AST, ALT, and LDH levels in sera of chickens in NZ9000/pTX8048, MDXEF-1/pTX8048 group, and infection control group were transiently and significantly elevated on $4 \mathrm{dpi}$ compared to PBS control group and four $\Delta$ Hexon-expressing bacteria groups, which indicating that severe pathological changes have occurred in liver (43). Meanwhile, the significant decrease in the levels of TP and ALB also suggested that protein synthesis was affected, which further demonstrated that the liver had been seriously damaged. This result is consistent with the previous research (38). Furthermore, the little-changed indexes of liver function in the four groups of chickens immunized with $\Delta$ Hexonexpressing bacteria also proved the protective effects against FAdV infection.

In the present study, on $5 \mathrm{dpi}$, typical pathological and histopathological changes were accordingly observed in the hearts, livers, and kidneys of chickens in the challenged control group, NZ9000/pTX8048 and MDXEF-1/pTX8048 group, including hydropericardium, splenomegaly, hepatomegaly, and nephritis, all of which are also recorded in other reports $(43,44)$. The pathological changes in hearts, livers, and kidneys of chickens in the four groups immunized with $\Delta$ Hexonexpressing bacteria were relatively slight, which suggested that the live bacteria expressing $\triangle$ Hexon-CWA protein protected against pathological injury of FAdV targeted organs. However, a $100 \%$ protection ratio was not observed in the present study, which may be explained by the fact that the virus strain FAdV-4/GX01 is highly virulent, and chickens were challenged by intramuscular injection way. In our preliminary test, chickens challenged with the lethal dose of FAdV-4/GX01 via intramuscular injection caused mortality of $90-100 \%$, which is close to the reported highest clinical mortality rate (45). The present results showed that the constructed four recombinant bacteria, especially E. faecalis expressing $\Delta$ Hexon protein, provided promising protection against the FAdV-4 infection.

Besides, it is worth noting that the viral load in the livers of the challenged chickens in the four groups immunizing with $\Delta$ Hexon-expressing bacteria is still high, although it is significantly lower than that in the infection control group. Recently, several studies have shown that Fiber 2 plays a vital role during the invasion of FAdV into host cells $(46,47)$. In some reports, the co-immunization of recombinant $\mathrm{LAB}$ expressing several target proteins is more promising $(48,49)$. Currently, another four kinds of live recombinant LAB expressing Fiber 2 protein have been constructed in our lab, and the subsequent co-immunization of live recombinant E. faecalis expressing $\Delta$ Hexon and Fiber 2 would be further explored.

Overall, these results demonstrated that recombinant L. lactis and $E$. faecalis delivering $\Delta$ Hexon protein could evoke strong systemic immune responses against FAdV infection, relieve pathological injury and functional damage in target organs, reduce virus load in liver to some extent, and prevent HPS caused by FAdV infection. The data presented in this report provide references for exploring potential vaccines for HPS. 


\section{DATA AVAILABILITY STATEMENT}

All data generated for this study are original and included in this article and its Supplementary Material. Any further inquiries may be directed to the corresponding author Dexing Ma.

\section{ETHICS STATEMENT}

The protocol of animal experiments was approved by the Animal Ethics Committee of Northeast Agricultural University NEAU2018-09-0232-12.

\section{AUTHOR CONTRIBUTIONS}

DM and ZJ designed the study. GL, CM, XP, XY, and ZJ prepared experimental materials. CM contributed to analytic tools. ZJ and $\mathrm{CM}$ analyzed the data and wrote the paper. ZJ, DM, CM, and

\section{REFERENCES}

1. Harrach B, Benko M. Phylogenetic analysis of adenovirus sequences. Methods Mol Med. (2007) 131:299-334. doi: 10.1007/978-1-59745-277-9_22

2. Hess M. Detection and differentiation of avian adenoviruses: a review. Avian Pathol. (2000) 29:195-206. doi: 10.1080/03079450050045440

3. Li H, Wang J, Qiu L, Han Z, Liu S. Fowl adenovirus species C serotype 4 is attributed to the emergence of hepatitis-hydropericardium syndrome in chickens in China. Infect Genet Evol. (2016) 45:230-41. doi: 10.1016/j.meegid.2016.09.006

4. Li G, Yu G, Niu Y, Cai Y, Liu S. Airborne transmission of a serotype 4 fowl adenovirus in chickens. Viruses. (2019) 11:262. doi: 10.3390/v11030262

5. Wang Z, Zhao J. Pathogenesis of hypervirulent fowl adenovirus serotype 4: the contributions of viral and host factors. Viruses. (2019) 11:741. doi: 10.3390/v11080741

6. Abdulaziz TA, Alattar MA. New syndrome in Iraqi chicks. Vet Rec. (1991) 129:272. doi: 10.1136/vr.129.12.272

7. Mazaheri A, Prusas C, Vos M, Hess M. Some strains of serotype 4 fowl adenoviruses cause inclusion body hepatitis and hydropericardium syndrome in chickens. Avian Pathol. (1998) 27:269-76. doi: 10.1080/03079459808419335

8. Kim JN, Byun SH, Kim MJ, Kim JJ, Sung HW, Mo IP. Outbreaks of hydropericardium syndrome and molecular characterization of korean fowl adenoviral isolates. Avian Dis. (2008) 52:526-30. doi: 10.1637/8178-112207-Case

9. Sohaimi NM, Bejo MH, Omar AR, Ideris A, Isa NM. Hexon and fiber gene changes in an attenuated fowl adenovirus isolate from Malaysia in embryonated chicken eggs and its infectivity in chickens. J Vet Sci. (2018) 19:759-70. doi: 10.4142/jvs.2018.19.6.759

10. Mase M, Nakamura K, Imada T. Characterization of fowl adenovirus serotype 4 isolated from chickens with hydropericardium syndrome based on analysis of the short fiber protein gene. J Vet Diagn Invest. (2010) 22:218-23. doi: 10.1177/104063871002200207

11. Zhao J, Zhong Q, Zhao Y, Hu Y, Zhang G. Pathogenicity and complete genome characterization of fowl adenoviruses isolated from chickens associated with inclusion body hepatitis and hydropericardium syndrome in China. PLoS ONE. (2016) 11:e0161744. doi: 10.1371/journal.pone.0 161744

12. Li PH, Zheng PP, Zhang T, Wen G, Shao H, Luo Q. Fowl adenovirus serotype 4: epidemiology, pathogenesis, diagnostic detection, and vaccine strategies. Poultry Sci. (2017) 96:2630-40. doi: 10.3382/ps/pex087

13. Longet S, Lundahl MLE, Lavelle EC. Targeted strategies for mucosal vaccination. Bioconjug Chem. (2018) 29:613-23. doi: 10.1021/acs.bioconjchem.7b00738
GL revised the manuscript. All authors reviewed the results and approved the final version of the manuscript.

\section{FUNDING}

This study was funded by grants from the National Natural Science Foundation of China (30901061 and 31973003).

\section{ACKNOWLEDGMENTS}

The authors wish to acknowledge GL for his kind donation of FAdV-4/GX01 strain.

\section{SUPPLEMENTARY MATERIAL}

The Supplementary Material for this article can be found online at: https://www.frontiersin.org/articles/10.3389/fvets. 2021.632218/full\#supplementary-material

14. Singh SK, Plieskatt J, Chourasia BK, Singh V, Bolscher JM, Dechering $\mathrm{KJ}$, et al. The Plasmodium falciparum circumsporozoite protein produced in Lactococcus lactis is pure and stable. J Biol Chem. (2020) 295:403-14. doi: 10.1074/jbc.RA119.011268

15. Wang M, Fu T, Hao J, Li L, Tian M, Jin N, et al. A recombinant Lactobacillus plantarum strain expressing the spike protein of SARS-CoV-2. Int J Biol Macromol. (2020) 160:736-40. doi: 10.1016/j.ijbiomac.2020.05.239

16. O'Flaherty S, Klaenhammer TR. Multivalent chromosomal expression of the Clostridium botulinum serotype A neurotoxin heavy-chain antigen and the Bacillus anthracis protective antigen in Lactobacillus acidophilus. Appl Environ Microbiol. (2016) 82:6091-101. doi: 10.1128/AEM.01533-16

17. Fingerut E, Gutter B, Gallili G, Michael A, Pitcovski J. A subunit vaccine against the adenovirus egg-drop syndrome using part of its fiber protein. Vaccine. (2003) 21:2761-6. doi: 10.1016/S0264-410X(03) 00117-8

18. Tian K, Guo H, Li N, Zhang Y, Wang Z, Wang B, et al. Protection of chickens against hepatitis-hydropericardium syndrome and Newcastle disease with a recombinant Newcastle disease virus vaccine expressing the fowl adenovirus serotype 4 fiber-2 protein. Vaccine. (2020) 38:1989-97. doi: 10.1016/j.vaccine.2020.01.006

19. Ruan S, Zhao J, Yin X, He Z, Zhang G. A subunit vaccine based on fiber-2 protein provides full protection against fowl adenovirus serotype 4 and induces quicker and stronger immune responses than an inactivated oil-emulsion vaccine. Infect Genet Evol. (2018) 61:145-50. doi: 10.1016/j.meegid.2018.03.031

20. Zhang J, Wei Y, Huang K, Sun X, Zou Z, Jin M. Baculovirusexpressed FAdV-4 penton base protein protects chicken against hepatitis-hydropericardium syndrome. J Integr Agr. (2019) 18:2598-604. doi: 10.1016/S2095-3119(19)62739-5

21. Shah MS, Ashraf A, Rahman M, Khan MI, Qureshi JA. A subunit vaccine against hydropericardium syndrome using adenovirus penton capsid protein. Vaccine. (2012) 30:7153-6. doi: 10.1016/j.vaccine.2012.10.013

22. Schachner A, Marek A, Jaskulska B, Bilic I, Hess M. Recombinant FAdV-4 fiber-2 protein protects chickens against hepatitishydropericardium syndrome (HHS). Vaccine. (2014) 32:1086-92. doi: 10.1016/j.vaccine.2013.12.056

23. Ma D, Gao M, Dalloul RA, Ge J, Ma C, Li J. Protective effects of oral immunization with live Lactococcus lactis expressing Eimeria tenella 3-1E protein. Parasitol Res. (2013) 112:4161-7. doi: 10.1007/s00436-013-3607-9

24. Wang D, Zhang Y, Ma C, Ma D, Zhao Q, Wang F, et al. Live recombinant Lactococcus lactis expressing avian hepatitis virus ORF2 protein: immunoprotection against homologous virus challenge in chickens. Vaccine. (2018) 36:1108-15. doi: 10.1016/j.vaccine.2018.01.003 
25. Chen W, Ma C, Wang D, Li G, Ma D. Immune response and protective efficacy of recombinant Enterococcus faecalis displaying dendritic celltargeting peptide fused with Eimeria tenella 3-1E protein. Poult Sci. (2020) 99:2967-75. doi: 10.1016/j.psj.2020.03.014

26. Huang H, Jiang Y, Zhou F, Shi C, Yang W, Wang J, et al. A potential vaccine candidate towards chicken coccidiosis mediated by recombinant Lactobacillus plantarum with surface displayed EtMIC2 protein. Exp Parasitol. (2020) 215:107901. doi: 10.1016/j.exppara.2020.107901

27. Yigang XU, Yijing LI. Construction of recombinant Lactobacillus casei efficiently surface displayed and secreted porcine parvovirus VP2 protein and comparison of the immune responses induced by oral immunization. Immunology. (2008) 124:68-75. doi: 10.1111/j.1365-2567.2007. 02738.x

28. Xu Y, Guan X, Liu Z, Tian C, Cui L. Immunogenicity in Swine of orally administered recombinant Lactobacillus plantarum expressing classical swine fever virus E2 protein in conjunction with thymosin $\alpha-1$ as an adjuvant. Appl Environ Microbio. (2015) 81:3745-52. doi: 10.1128/AEM.00 127-15

29. Wells JM. Mucosal vaccination and therapy with genetically modified lactic acid bacteria. Annu Rev Food Sci Technol. (2011) 2:423-45. doi: 10.1146/annurev-food-022510-13 3640

30. Owen JL, Sahay B, Mohamadzadeh M. New generation of oral mucosal vaccines targeting dendritic cells. Curr Opin Chem Biol. (2013) 17:918-24. doi: 10.1016/j.cbpa.2013.06.013

31. Ma C, Zhang L, Gao M, Ma D. Construction of Lactococcus lactis expressing secreted and anchored Eimeria tenella 3-1E protein and comparison of protective immunity against homologous challenge. Exp Parasitol. (2017) 178:14-20. doi: 10.1016/j.exppara.2017.05.001

32. Reed LJ, Muench H. A simple method of estimating fifty per cent endpoints. Am J Epidemiol. (1938) 27:493-7. doi: 10.1093/oxfordjournals.aje. a118408

33. Günes A, Marek A, Grafl B, Berger E, Hess M. Real-time PCR assay for universal detection and quantitation of all five species of fowl adenoviruses (FAdV-A to FAdV-E). J Virol Methods. (2012) 183:147-53. doi: 10.1016/j.jviromet.2012.04.005

34. Kapczynski DR, Jiang H, Kogut MH. Characterization of cytokine expression induced by avian influenza virus infection with realtime RT-PCR. Methods Mol Biol (Clifton, NJ). (2014) 1161:217-33. doi: 10.1007/978-1-4939-0758-8_18

35. Li J, Wang F, Ma C, Huang Y, Wang D, Ma D. Recombinant Lactococcus lactis expressing Eimeria tenella AMA1 protein and its immunological effects against homologous challenge. Exp Parasitol. (2018) 191:1-8. doi: 10.1016/j.exppara.2018.05.003

36. Bustin SA, Benes V, Garson JA, Hellemans J, Huggett J, Kubista M, et al. The MIQE guidelines: minimum information for publication of quantitative real-time PCR experiments. Clin Chem. (2009) 55:611-22. doi: 10.1373/clinchem.2008.112797

37. Ma C, Li G, Chen W, Jia Z, Yang X, Pan X, et al. Eimeria tenella: IMP1 protein delivered by Lactococcus lactis induces immune responses against homologous challenge in chickens. Vet Parasitol. (2020) 289:109320. doi: 10.1016/j.vetpar.2020.109320
38. Niu Y, Sun Q, Liu X, Liu S. Mechanism of fowl adenovirus serotype 4-induced heart damage and formation of pericardial effusion. Poult Sci. (2019) 98:1134-45. doi: 10.3382/ps/pey485

39. Mcferran JB, Adair BM. Avian adenoviruses - a review. Avian Pathol. (1977) 6:189-217. doi: 10.1080/03079457708418228

40. Yu B, Dong J, Wang C, Zhan Y, Zhang H, Wu J, et al. Characteristics of neutralizing antibodies to adenovirus capsid proteins in human and animal sera. Virology. (2013) 437:118-23. doi: 10.1016/j.virol.2012.12.014

41. Li G, Ma C, Wang D, Chen W, Ma D. Recombinant Lactococcus lactis co-expressing dendritic cell target peptide and E. tenella 3-1E protein: immune response and efficacy against homologous challenge. Food Agr Immunol. (2020) 31:379-92. doi: 10.1080/09540105.2020.1733495

42. Cook JKA. Fowl adenoviruses: studies on aspects of the pathogenicity of six strains for 1-day-old chicks. Avian Pathol. (1983) 12:35-43. doi: 10.1080/03079458308436147

43. Niu Y, Sun Q, Zhang GG, Sun W, Liu X, Xiao Y, et al. Pathogenicity and immunosuppressive potential of fowl adenovirus in specific pathogen free chickens. Poult Sci. (2017) 96:3885-92. doi: 10.3382/ps/pex206

44. Niu Y, Sun W, Zhang GG, Qu Y, Wang P, Sun H, et al. Hydropericardium syndrome outbreak caused by fowl adenovirus serotype 4 in China in 2015. J Gen Virol. (2016) 97:2684-90. doi: 10.1099/jgv.0.000567

45. Kim M, Lim T, Lee D, Youn H, Yuk S, Kim B, et al. An inactivated oilemulsion fowl Adenovirus serotype 4 vaccine provides broad cross-protection against various serotypes of fowl Adenovirus. Vaccine. (2014) 32:3564-8. doi: 10.1016/j.vaccine.2014.03.015

46. Zhang Y, Liu R, Tian K, Wang Z, Yang X, Gao D, et al. Fiber2 and hexon genes are closely associated with the virulence of the emerging and highly pathogenic fowl adenovirus 4. Emerg Microbes Infect. (2018) 7:199. doi: 10.1038/s41426-018-0203-1

47. Wang P, Zhang J, Wang W, Li T, Liang G, Shao H, et al. A novel monoclonal antibody efficiently blocks the infection of serotype 4 fowl adenovirus by targeting fiber-2. Vet Res. (2018) 49:1-7. doi: 10.1186/s13567-018-0525-y

48. Timmerman HM, Koning CJM, Mulder L, Rombouts FM, Beynen AC. Monostrain, multistrain and multispecies probiotics-A comparison of functionality and efficacy. Int J Food Microbiol. (2004) 96:219-33. doi: 10.1016/j.ijfoodmicro.2004.05.012

49. Talebi A, Amirzadeh B, Mokhtari B, Gahri H. Effects of a multi-strain probiotic (PrimaLac) on performance and antibody responses to Newcastle disease virus and infectious bursal disease virus vaccination in broiler chickens. Avian Pathol. (2008) 37:509-12. doi: 10.1080/03079450802356995

Conflict of Interest: The authors declare that the research was conducted in the absence of any commercial or financial relationships that could be construed as a potential conflict of interest.

Copyright (C) $2021 \mathrm{Jia}, \mathrm{Ma}$, Yang, Pan, Li and Ma. This is an open-access article distributed under the terms of the Creative Commons Attribution License (CC BY). The use, distribution or reproduction in other forums is permitted, provided the original author(s) and the copyright owner(s) are credited and that the original publication in this journal is cited, in accordance with accepted academic practice. No use, distribution or reproduction is permitted which does not comply with these terms. 